\title{
Learning Models Development Based on Biblical Christianity Worldview in World History Courses
}

\author{
$1^{\text {st }}$ Jossapat Hendra Prijanto \\ Social Studies Education, Faculty of Education, UPH \\ Tangerang, Indonesia \\ jossapat.hendra@uph.edu
}

\author{
$2^{\text {nd }}$ Budi Wibawanta \\ Social Studies Education, Faculty of Education, UPH \\ Tangerang, Indonesia \\ budi.wibawanta@uph.edu
}

\begin{abstract}
The learning model in the World History course that is in accordance with the Biblical perspective can have an impact, especially on students in perceiving topics in the course. The purpose of this study is finding student learning experiences in world history courses, and to develop a biblical Christian worldview-based learning model on world history courses. The research method adapted the systemic design of Instruction Dick and Carey with the research subjects as many as 22 respondents. The results showed that the results of the calculation and analysis of questionnaire data on student learning experiences in world history courses showed findings that were categorized as very high or strongly agreed. The percentage of the learning model is divided into 8 indicators: student learning motivation $(\mathbf{8 8 . 1 8 \%})$, student access to learning resources $(84.24 \%)$, student discipline in managing study time $(85.45 \%)$, student learning habits ( $85.91 \%)$, the level of students' initial understanding of lecture competencies $(\mathbf{8 6 . 8 8 \%})$, subject competencies $(\mathbf{8 7 . 7 3 \%})$, foundation framework courses $(94.56 \%)$. It was concluded that the development of the Biblical Christian worldview-based learning model in the World History course refers to the student learning experience is very necessary to take into account the learning model categories that are manifested in the form of textbooks that facan be easily understood, integrated with Biblical Christian worldview.
\end{abstract}

Keywords: development, learning model, biblical christianity worldview, World History Course

\section{INTRODUCTION}

Through the course of World History, students are expected to be able to find perspectives on historical events and knowledge of History focused on the development of civilization, education, Indonesia's struggle along with the development of other Asian countries' struggles, and the emergence of new understandings of Europe brought by the West through colonialism and modern imperialism. The main purpose of learning history of the world, students are expected to be able to analyze, assess, and reflect on what has been done by society and nation, both past and present civilizations based on the biblical Christian worldview. This course looks at history in a Christian perspective that begins with creation, fall, redemption, and fulfillment where God works actively and sovereignly in historical events.

In understanding World History, students can find the perspective of historical events and knowledge of World History, where all that knowledge comes from the mind of God and is a perfect, absolute, and ultimate truth in the form of the Person, namely the Word, the Lord Jesus Christ. The Biblical Christian perspective provides a perspective of past events that provide hope in the future, because we need not fear the future. But in fact, learning about World History currently both in schools and colleges is more about how to give the material of World History to the cognitive students.

If learning is structured and developed on a sound basis, World History teachers or instructors can play a role in helping students shape their worldview. Students or students who are seen from the age factor still desperately need help in developing their values, attitudes and beliefs so they can use them to make choices in their lives. Therefore, we need a learning model that is supported by clear learning goals, delivery strategies, effective learning media and content that is suitable with the learning objectives. This of course will help students reflect and promote thinking in discussions about themes or topics in the World History course. This study seeks to design how the learning model in the World History course is in accordance with the Biblical perspective so that it can have a special impact on students in perceiving topics in the course.

Development of a Biblical Christian worldview-based learning model in the course of World History, which is about the need to develop learning models that are relevant and significant to students who can understand these subjects easily, integrated with biblical Christian worldview, and can find historical events and historical knowledge. The world as a scientific field under study. Through learning about world history, students can analyze, assess, and reflect on activities carried out by society and nation, both past and present based on the Biblical Christian worldview, namely that human history begins with creation, the fall of man in sin, and redemption by Jesus Christ on the cross, and sanctification after the second 
coming of Jesus which is a past hope, namely that God works actively and sovereignly in historical events. It is hoped that through the development of this learning model it can be produced in the form of international proceedings that can contribute ideas to academics in the scientific field related to textbooks that can provide a variety of information related to the competencies of world history courses that can be easily understood, integrated with character traits for student life.

This research purpose is to find out student learning experiences in world history courses, and develop a biblical Christian worldview based, learning model on world history courses.

\section{LITERATURE REVIEW}

According to Joyce, Weil, and Calhoun, "A model of teaching is a way of building a positive and stimulating environment which students learn interacting with its components [1]. The teaching model is a way to build understanding and stimulate ecosystems where learners learn through interaction with their components. The effect of feedback is a learning goal that is more a by-product of learning outcomes, achieved because students face the system

Certain learning environment. For example, students are able to think critically, be more open to accepting other people's opinions, creative, and disciplined. It can be concluded that the learning model is how the instructor can help students to become intelligent and reliable learners through information, ideas, skills, values, ways of thinking, and actualizing themselves.

A brief definition is given by Dick, Carey, \& Carey, "Instructional design (ID) is used as an umbrella term that includes all phases of the ISD process. George M. Piskurich states, "Instructional design is really a set of rules for creating training that does what it is supposed to do". Learning design is a series of rules or procedures for creating the training that should be. Several procedures must be carried out to obtain the training objectives. Basically, the design of learning is a way to plan training since the emergence of ideas to complete the initial revision of the work and are ready to run the program again. $M$ Li defines, "Instructional Design is a systematic process of analyzing the need for instruction, designing effective content, developing training based on sound instructional principles, implementing instruction by delivering it to learners, and evaluating the effect of instruction. Learning design is a systematic process of analyzing the need for learning, designing effective content, compiling training based on learning principles, implementing learning by conveying to students, and evaluating the effects of learning.

From the definition mentioned above it can be concluded that learning design has the following characteristics:

1. Is a series of systematic procedures to create an effective, efficient, interesting and reliable learning.

\section{Achieve learning objectives.}

3. Using learning, communication and media theories.

From these characteristics it can be concluded that learning design is a systematic series of procedures to create an effective, efficient, interesting, and reliable learning in achieving learning goals based on learning theory, communication and media. Research on the research and development (R \& D) model continues to grow. Rita C. Richey and James D. Klein refer to R \& D as Design and Development Research (DDR) in which a study was also carried out. Because as a science, design and development must be tied to an understanding built on empirical research. The solution to the problem must also be supported by data. In generating knowledge, understanding the field more fully, and having the ability to make predictions, DDR is divided into two categories of research, namely (1) research on products and devices; (2) research in model design and development. In this study referring to the first category, which is conducting research and development that produces products using the design of the development of existing learning.

Kuswono in HISTORIA Journal Volume 5, Number 1, Year 2017. Declared that the need to develop historical learning modules integrated the value of religious character, which implements integrated learning of religious characters so as to be able to increase cognitive and affective aspects and foster behavior that is in accordance with Islamic values. The results of the module feasibility test show that the quality of the module is in the results of the module feasibility test showing that the quality of the module is in good criteria with an average value of 78 [2].

Maulana Muhammad in the History of Education Journal Vol 7, No. 1, 2018 entitled "Development of Historical Learning Modules for High Schools in the City of Palembang, states that development research uses a model of dick and carey. The values obtained in the validation process are material: 3.80 languages: 3.90 and learning design: 4.00. Everything is in the valid category. By using this valid product, the potential effect is proven by the researcher getting a pretest score of $25.9 \%$ and posttest of $77.0 \%$ after a field trial. This shows an increase of $51.1 \%$ with an N-Gain value of $0.68 \%$ so that it can be concluded that the learning media module history of war material for five days and five nights for high school in Palembang is valid and practical [3].

Dimas Anggoro in his thesis, entitled the development of national teaching material, a revolution to increase nationalism of students. Stating that the independent sample t test showed differences in the effect of using instructional materials on increasing student nationalism reaching $25.17 \%$ with a probability value $=0.00$ smaller than alpha $=0.05$. Modules that have a greater influence on student nationalism than conventional teaching materials (handouts) with the posttest nationalism score of the experimental class at 85.53 (very good) while the control class at 77.00 (good) [4]. 
Thus the module can help students learn independently supported by clear learning goals, delivery strategies, effective learning media and content that is suitable with the learning objectives. The study designed how the learning model in the World History course fits in with the Biblical perspective so that it can have a special impact on students in perceiving topics in the course.

\section{METHODS}

This research is a development research in the field of education (Educational Research and Development / R \& D) that uses a qualitative approach. The development model used in this study adapts The Systematic Design of Instruction (Dick, Carey, and Carey) as the Steps of System Approach Model of Educational Research and Development, which is the model most widely used for education research and development. the Dick, Carey, and Carey models are product-oriented models but also system-oriented, depending on the size and scope of stepby-step assessment activities or needs analysis in determining general learning goals. The steps for developing the learning model can be seen in fig 1 .

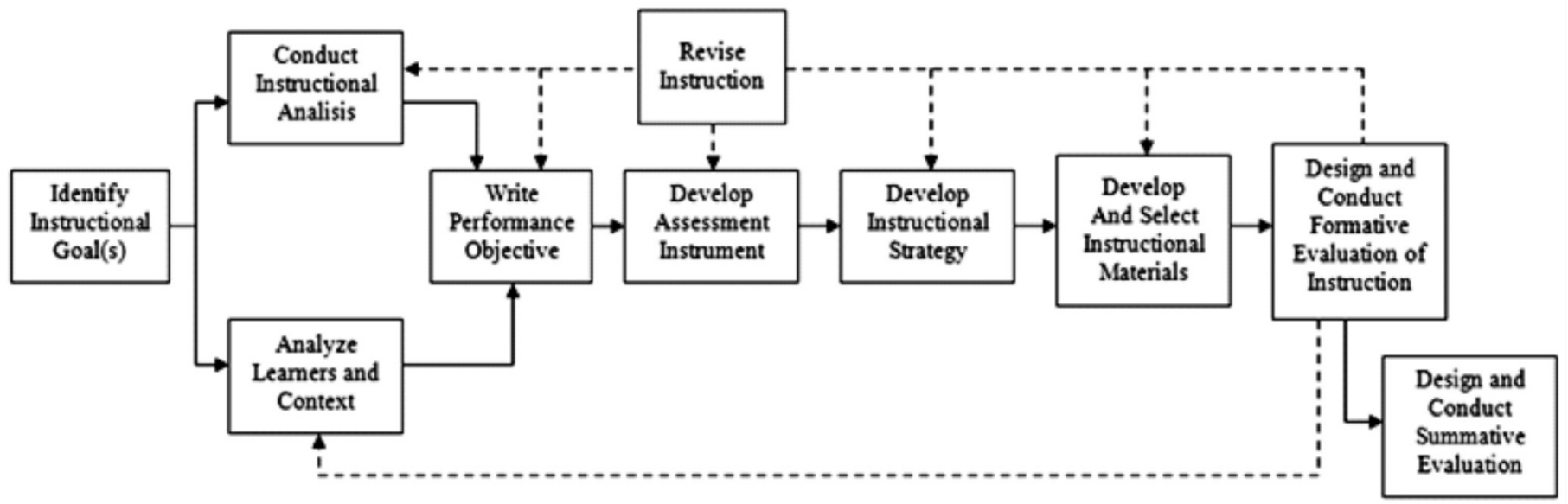

Fig 1. The Systematic Design of Instruction

The steps as described in Dick, Carey and Carey are: Identifying General Learning Objectives, conducting learning analysis, analyzing students and contexts, writing performance goals, developing assessment instruments, developing learning strategies, developing and selecting learning materials, evaluating, revise learning, design and carry out summative evaluations.
Each question item in the respondent questionnaire was made in the form of coding in accordance with the study aspects of student learning experience related to the formulation of research problems for the effectiveness of presenting research data in the form of bar charts to be discussed at. The following coding table will be included.

TABLE I. STUDENT LEARNING EXPERIENCE RELATED TO THE FORMULATION OF RESEARCH PROBLEMS

\begin{tabular}{|c|c|c|c|}
\hline Student learning aspects & No & Statement item & Coding \\
\hline \multirow{3}{*}{$\begin{array}{l}\text { Student Learning } \\
\text { Motivation }\end{array}$} & 1 & I get a strong external drive (external factor) to study World history education courses & A1 \\
\hline & 2 & I have a strong internal drive for the World History Education course & $\mathrm{A} 2$ \\
\hline & 3 & $\begin{array}{l}\text { I have a high curiosity about the competencies of knowledge, skills, and behavior that must be mastered in } \\
\text { the course of World History education }\end{array}$ & A3 \\
\hline \multirow{4}{*}{$\begin{array}{l}\text { Student Access to } \\
\text { Learning Resources }\end{array}$} & 4 & I can easily access textbooks, online books, or other sources related to the course in world history education & B1 \\
\hline & 5 & I can use the moodle learning system to access World History Education material available in it & B2 \\
\hline & 6 & $\begin{array}{l}\text { I visited the campus library to access literature as well as important information relating to the World } \\
\text { history Education course }\end{array}$ & B3 \\
\hline & 7 & $\begin{array}{l}\text { I easily get World History Education material that is in accordance with the demands of the UPH FIP- } \\
\text { curriculum }\end{array}$ & B4 \\
\hline $\begin{array}{l}\text { Student Discipline in } \\
\text { Managing Learning } \\
\text { Time }\end{array}$ & 8 & I am used to managing study time consistently every day & $\mathrm{C} 1$ \\
\hline
\end{tabular}




\begin{tabular}{|c|c|c|c|}
\hline Student learning aspects & No & Statement item & Coding \\
\hline & 9 & I am always disciplined in keeping the learning schedule that has been made & $\mathrm{C} 2$ \\
\hline & 10 & I collected assignments on time & $\mathrm{C} 3$ \\
\hline \multirow[t]{4}{*}{ Student Learning Habits } & 11 & I have become accustomed to studying regularly and systematically & D1 \\
\hline & 12 & I often think of the application of knowledge that I learned with real practice in the field & D2 \\
\hline & 13 & $\begin{array}{l}\text { I find it easier to understand the explanation of the material when meeting face to face with the lecturer in } \\
\text { the lecture hall }\end{array}$ & D3 \\
\hline & 14 & I have a habit of studying independently & D4 \\
\hline \multirow{7}{*}{$\begin{array}{l}\text { Level of Early Student } \\
\text { Understanding of } \\
\text { Lecture Competence }\end{array}$} & 15 & $\begin{array}{l}\text { I was able to analyze World History in a Christian perspective that began with creation, fall, redemption } \\
\text { and fulfillment where God worked actively in historical events of the World }\end{array}$ & E1 \\
\hline & 16 & $\begin{array}{l}\text { I can analyze, assess, and reflect on World History, concerning the activities of society and the nation, both } \\
\text { past and present civilizations }\end{array}$ & E2 \\
\hline & 17 & $\begin{array}{l}\text { I can understand World History, which is focused on the development of civilization, education, the } \\
\text { struggle of Indonesia along with the development of the struggles of the Asian nations }\end{array}$ & E3 \\
\hline & 18 & $\begin{array}{l}\text { I can understand the emergence of new understandings from Europe that brought the West to Indonesia } \\
\text { through Colonialism and modern Imperialism }\end{array}$ & E4 \\
\hline & 19 & I can easily follow the lecture process and understand the direction of the lecturer well & E5 \\
\hline & 20 & I can do the assignments given by the lecturer very well & E6 \\
\hline & 21 & I can understand the material delivered by the lecturer about a topic & E7 \\
\hline \multirow[t]{4}{*}{ Course Competence } & 22 & $\begin{array}{l}\text { Course competencies, make me have a historical perspective and knowledge of World History, that } \\
\text { historical knowledge comes from the mind of God and is a perfect truth }\end{array}$ & F1 \\
\hline & 23 & $\begin{array}{l}\text { Course competencies, made me apply logical, critical, systematic, and innovative thinking in the context of } \\
\text { developing or implementing World History learning }\end{array}$ & $\mathrm{F} 2$ \\
\hline & 24 & The competency of the World History course can improve my ability as a Christian Teacher & F3 \\
\hline & 25 & Course competencies make me more challenged to study World History & F4 \\
\hline \multirow[t]{3}{*}{$\begin{array}{l}\text { Foundation Framework } \\
\text { Courses }\end{array}$} & 26 & I understand that God works actively and sovereignly in historical events & G1 \\
\hline & 27 & $\begin{array}{l}\text { I understand that the true center of history is the Cross of Christ, in which there is a human development } \\
\text { which begins with the process of creation, the fall of sin, and the redemption of Jesus Christ on the cross. }\end{array}$ & G2 \\
\hline & 28 & I understand that Jesus' second coming to the earth in it was a past hope in the story of World History & G3 \\
\hline
\end{tabular}

\section{RESULT AND DISCUSSION}

\section{A. Student Learning Experience}

\section{1) Student Learning Motivation}

Based on the results of the respondents' questionnaire calculations on aspects of student learning motivation with a range of answers of 22 respondents in the A1 statement item, it has shown a Likert scale achievement of $86.36 \%$ with very high interpretation criteria or strongly agree. Likewise, on question item A2 has shown the achievement of the Likert scale 88.18\% with very high interpretation criteria or strongly agree. In addition, the A3 statement item shows the Likert scale achievement of $90 \%$ with very high interpretation criteria. Based on the scale of the Likert scale on the three items above, it shows that students' learning motivation to study the World History course is in the range of very high interpretation criteria. Based on the achievement of the student's very high learning motivation, it needs to be addressed continuously with learning models that are relevant and significant such as the provision of teaching materials that can be easily accessed. This will greatly support student learning motivation so that motivation can be maintained for further learning (fig 2).

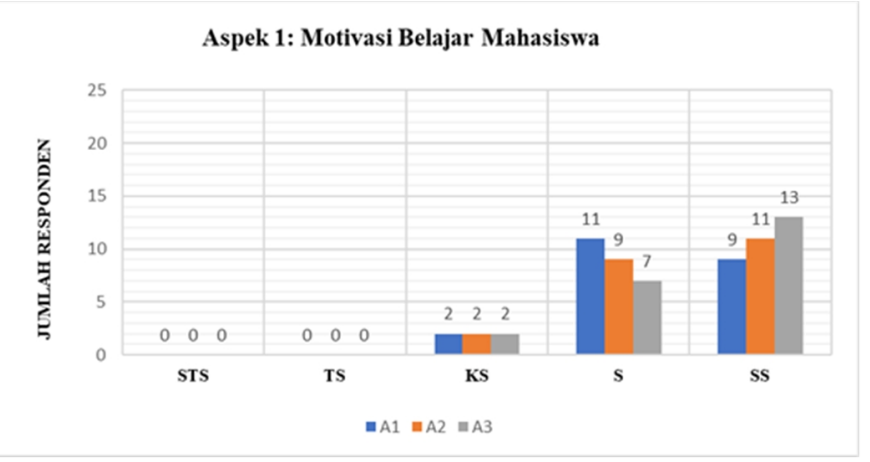

Fig 2. Student Learning Motivation

\section{2) Student Access to Learning Resources}

Based on the results of the calculation of the questionnaire distributed to 22 respondents for aspects of student access to learning resources showed the achievement of the Likert scale on item B1 statement amounting to $85.45 \%$ with very high interpretation criteria. The B2 statement item shows the Likert scale achievement of $84.55 \%$ with very high interpretation criteria. The item B3 statement shows a Likert scale achievement of $82.73 \%$ with very high interpretation criteria. The B4 statement item shows the Likert scale achievement of $88.18 \%$ with very high interpretation criteria. Based on the 
interpretation of the achievement of the Likert scale, it shows that student access to learning resources is in the range of very high interpretation criteria. However, the achievements in this aspect still need to be improved, especially in the B3 statement items, namely students visiting campus libraries to access literature and important information related to World history Education courses because the availability of reading material must be updated and relevant so that it can be used as reading material or reference in information search to broaden students' horizons. It is also related to item B4 statement, namely the convenience of students to get World History Education material that is in accordance with the demands of the UPH FIPcurriculum. When students have difficulty getting material that is in accordance with the demands of the UPH FIP-curriculum, then visits to campus libraries will also be increasingly rare due to the limitations of relevant reading material (fig 3 ).

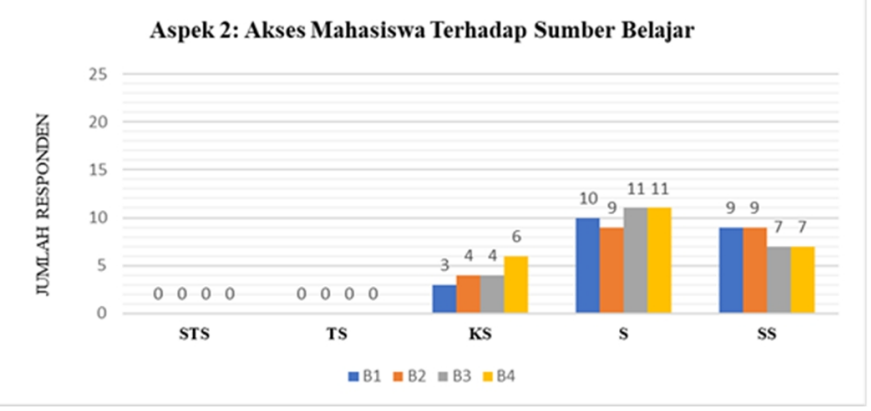

Fig 3. Student Access to Learning Resources

\section{3) Student Discipline in Managing Learning Time.}

Based on the results of the calculation of the questionnaire distributed to 22 respondents for the aspects of student discipline in managing the study time, the achievement of the Likert scale on the item $\mathrm{C} 1$ was $76.36 \%$ with high interpretation criteria. The item C2 statement shows a Likert scale achievement of $83.64 \%$ with very high interpretation criteria. The item C3 statement shows a Likert scale achievement of $96.36 \%$ with very high interpretation criteria. Based on the interpretation of the achievement of the Likert scale on the three items above statement shows that student discipline in managing study time is in the range of high interpretation towards very high. However, achievements in this aspect still need to be improved, especially in the item $\mathrm{C} 1$ statement which states that students are still less accustomed to regulating time to study consistently every day. Even though it is still relatively small, but if it continues to be allowed it will be very possible to have an impact on reducing the ability of students to understand the competencies of the World History course due to inconsistency and discipline to the time of study. Starting from the assumption above, the development of a contextual learning model is needed so that it can help conditioning student learning time more effectively through formulation of competencies lectures with relevant and significant teaching materials in one text book that is easily understood, integrated with Christian worldview Bible, and applicable for college student (fig 4).

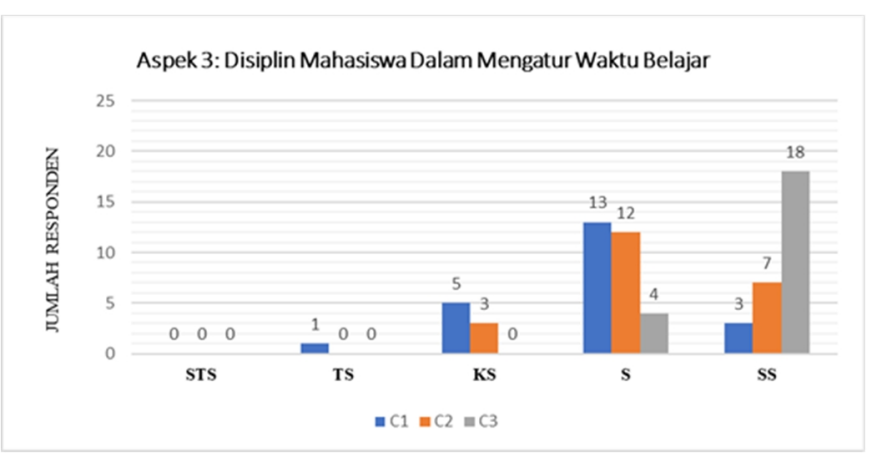

Fig 4. Student Discipline in Managing Learning Time

\section{4) Student Learning Practices}

Based on the results of the calculation of the questionnaire distributed to 22 respondents for aspects of learning practices students showed achievement of the Likert scale on item D1 statement amounting to $82.73 \%$ with very high interpretation criteria. On item D2 statement shows the Likert scale achievement of $86.36 \%$ with very high interpretation criteria. The item D3 statement shows a Likert scale achievement of $89.09 \%$ with very high interpretation criteria. The item D4 statement shows a Likert scale achievement of $85.45 \%$. Based on the interpretation of the Likert scale achievement on the four items above statement shows that student learning habits are in a very high interpretation range. Referring to the results of the calculation of the data in the item D1 statement above, it shows that 3 of the total respondents are still not used to learning regularly and systematically. It means that the development of learning models in the form of textbooks has a great opportunity to help students learn regularly and systematically follow the learning guidelines according to the lecture competencies contained in the textbook so that they are not only dependent on mentoring lecturers in a participatory manner (fig 5).

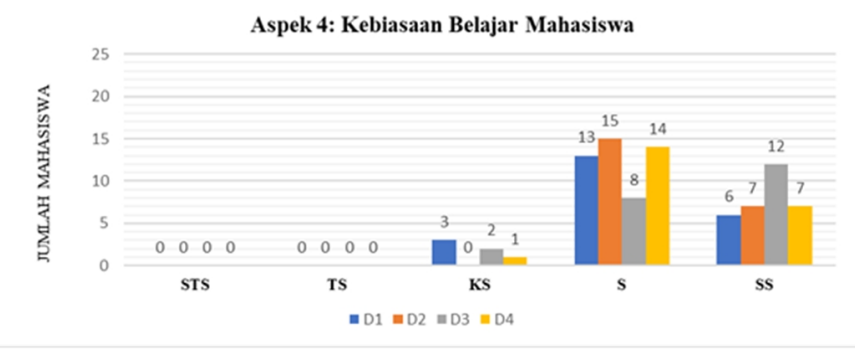

Fig 5. Student Learning Practices 


\section{5) Level of Early Student Understanding of Lecture} Competence

Based on the results of the calculation of the questionnaire distributed to 22 respondents for the aspects of the students' initial level of understanding of lecture competencies, the achievement of the Likert scale on E1 statement items was $88.18 \%$ with very high interpretation criteria. The item E2 statement shows a Likert scale achievement of $84.55 \%$ with very high interpretation criteria. The item E3 statement shows a Likert scale achievement of $85.45 \%$ with very high interpretation criteria. The E4 statement item shows the Likert scale achievement of $86.36 \%$. in the statement item E5 shows the achievement of the Likert scale of $90.91 \%$ with very high interpretation criteria. The item E6 statement shows a Likert scale achievement of $85.45 \%$ with very high interpretation criteria. The E7n statement item shows a Likert scale achievement of $87.27 \%$. Based on the interpretation of the Likert scale achievement on the seven items above statement shows that the level of students' initial understanding of lecture competencies is in a very high interpretation range. This means that students have been able to understand the subject competencies well so that they will facilitate students to absorb information conveyed by lecturers, especially guided by relevant and significant textbooks (fig 6).

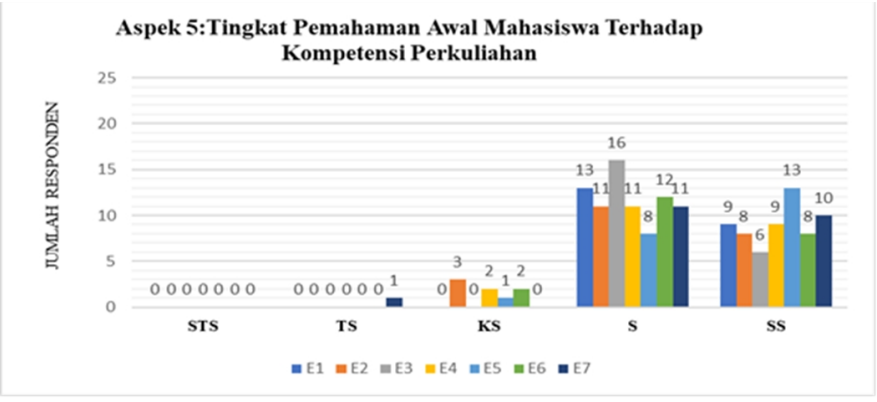

Fig 6. Level of Early Student Understanding of Lecture Competence

\section{6) Course Competence}

Based on the results of the calculation of the questionnaire distributed to 22 respondents for the subject competency aspects, the achievement of the Likert scale on F1 statement items was $86.36 \%$ with very high interpretation criteria. The item F2 statement shows a Likert scale achievement of $88.18 \%$ with very high interpretation criteria. The item F3 statement shows a Likert scale achievement of $87.27 \%$ with very high interpretation criteria. The item F4 statement shows a Likert scale achievement of $89.09 \%$. Based on the interpretation of the Likert scale achievement on the four items above statement shows that the level of students' initial understanding of the competencies of the World History course is in a very high interpretation range. When referring to this aspect statement item, the relevance of the World History course has been with the profile of graduates of education science students through learning in World History courses. Thus the achieved relevance that has been achieved well can continue to be maintained even enhanced through the development of Biblical Christian worldview-based learning (fig 7).

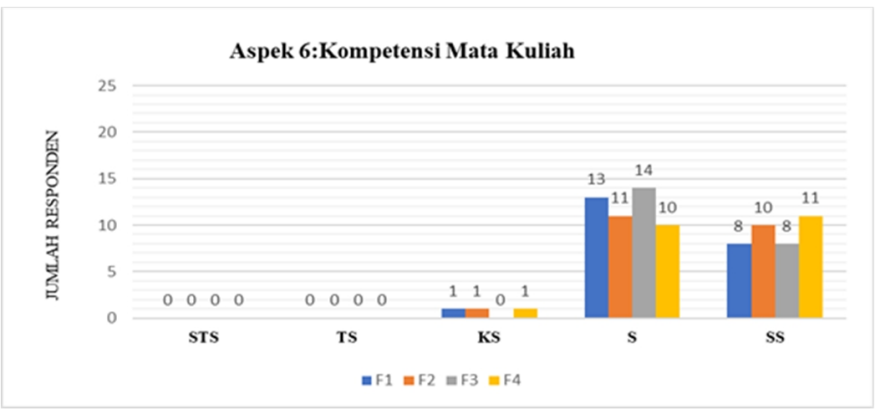

Fig 7. Course Competence

\section{7) Course Foundational Framework}

Based on the results of the calculation of the questionnaire distributed to 22 respondents for the foundation framework aspect the subject shows the achievement of the Likert scale on the item G1 statement of $96.36 \%$ with very high interpretation criteria. The item G2 statement shows the Likert scale achievement of $94.55 \%$ with very high interpretation criteria. The G3 statement item shows the Likert scale achievement of $92.73 \%$ with very high interpretation criteria. Based on the interpretation of the Likert scale achievement on the three items above statement shows that the level of students' initial understanding of the foundation framework of the World History course is in a very high interpretation range. This means learning World History courses that are integrated with biblical Christian worldviews have succeeded in helping students embody the competencies of their courses through daily life, referring to the item statement of this aspect. The hope is that with the development of this Biblical Christian worldview-based learning model, student achievement towards the foundational framework of courses is increasing, so that they not only learn conceptually, but how to show responsiveness to dynamic changes in this disruption era through relevant learning and significant (fig 8).

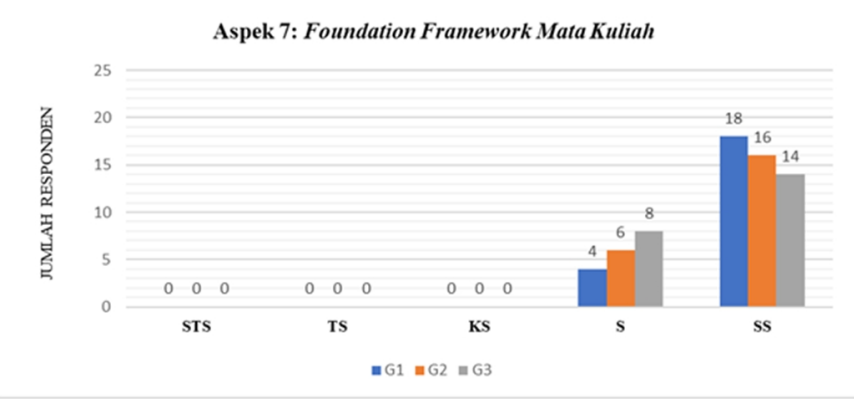

Fig 8. Course Foundational Framework 


\section{B. Development of Biblical Christian Worldview Based Learning Models}

After calculating and analyzing the data on all aspects of student learning experience, the next discussion is explained about the development of Biblical Christian worldview-based learning models as a study of the research problem formulation of the World History Education course. Looking at various things that still need to be improved on statement items referring to aspects of student learning experience through the availability of textbooks as the embodiment of research and development in the development of learning models as mentioned above, can be described through the systematics of ISBN textbooks as well as the contents of the content as follows:

- Topics per chapter, which contains the topic topics that are the focus of the study and the reference to the discussion adjusted to the competency of the subject.

- Learning Outcomes, which consist of explanations of subject competencies to be achieved during the range of learning by referring to the learning outcomes of graduate study programs based on Biblical Christianity.

- Enduring Understanding, lifelong understanding that is part of the focus of the study in each chapter contains the essence or nature of the course which later after learning is expected that students have the ability to have the ability to apply the meaning of learning delivered through the content of each subject competency stored in Their long term memory, so the character values are clearly stated in this section. Through appropriate enduring understanding, the student learning experience can be improved, especially in terms of the level of students' initial understanding of lecture competencies, subject competencies, and student learning habits.

- Essential Question, which includes fundamental questions that are relevant to the context of everyday student life that have significant meaning to philosophical foundations referring to the enduring understanding formula which is integrated with the principles of biblical Christian worldview. Through these philosophical questions, students will be increasingly challenged to explore their understanding of the topics presented in the learning process. The hope, student learning experience will increase, especially in aspects of student learning motivation, student discipline in managing study time, as well as foundational frame work courses.

- Description and scope, which contains the description of the topic and sub-topics to be discussed in reference to the competency of the course, the scope must be determined so that the discussion of topics in the material description remains focused.
- Relevance of Learning and Biblical Christian Worldview Studies. The relevance of learning is part of the uniqueness of this learning model. In the section imi contains updates on the latest information relating to the topics to be discussed where relevance and significance are based on Biblical Christian worldview. The religious values and philosophy of education explained in detail are correlated with the understanding of the perspective of world history based on the perspective of the Christian Faith which refers to subject competencies, which among others we can see in the form of: the purpose of defense, material description, material summaries, formative tests

\section{CONCLUSION}

Referring to the results of calculation and analysis of questionnaire data on student learning experiences in world history courses shows findings: achievement of student learning motivation needs to be addressed continuously with relevant and significant learning models including the availability of teaching materials that can be easily accessed, so motivation student learning can continue to be improved, the availability of relevant and significant relevant textbooks with learning is still very limited, especially those that are easily understood, integrated with biblical Christian faculty, low levels of regular student visits to the UPH-JO Library due to limited textbooks relevant, students are still not accustomed to regulating time to study consistently every day, students are still not used to learning regularly and systematically and do not have independent learning habits, relevance of competency courses with profile of graduates of TC-UP $\mathrm{H}$ has been achieved, learning that is integrated with biblical Christian worldview has succeeded in helping students have perspectives on world history according to the Christian faith.

Development of a Biblical Christian worldview-based learning model in World History courses referring to student learning experiences is very necessary to take into account: student learning motivation, student access to learning resources, student discipline in managing study time, student learning habits, level students' initial understanding of lecture competencies, course competencies, foundation framework courses. The development of the intended learning model is presented in the form of an output of an ISBN textbook (textbook) that can be easily understood, integrated with biblical Christian worldview.

\section{ACKNOWLEDGMENT}

In connection with the conclusions of the research above, the advice given for the research continuity plan is the number of respondents need to be added so that it is more representative with the scope of the research. In addition, questionnaire instruments need to be prepared in the form of a description, so that the respondent's answers are not only limited to filling in the 
the Social Studies. Sicence Research Associates. Palo Alto, California: Palo Alt

questionnaire instrument checklist. This research is still limited to output in the form of ISBN textbooks (textbooks), so that further research is expected to develop learning models in the form of digital learning media software, especially for the realm of simulation calculations on all topics contained in the textbook. Therefore, the results of this study will be published at the International Conference on Social Studies and Environmental Issues (ICOSEI) on September 19-20, 2019 at the State University of Malang, in the form of proceedings so that participants and other speakers can respond to the sustainability of the research

\section{REFERENCES}

[1] Anggoro, Dimas. (2016). Pengembangan modul bahan ajar sejarah Joyce, Bruce, Marsha Weil, Rhoada Wald, (2014). Three Teaching Strategies tor
[2] Kuswono, Cahaya Khaeroni, (2017), pengembangan modul sejarah pergerakan indonesia terintegrasi nilai karakter religius. Diambil pada $\begin{array}{lllll}\text { tanggal } & 20 & \text { Juli } & 2019 & \text { dari }\end{array}$ http://ojs.fkip.ummetro.ac.id/index.php/sejarah/article/view/730/589

[3] Maulana Muhammad, Hudaidah, Supriyanto. (2018). Pengembangan modul pembelajaran sejarah untuk sekolah menengah atas di kota Palembang. diambil pada tanggal 20 juli 2019. Dari https://ejournal.unsri.ac.id/index.php/criksetra/article/view/5300/2858

[4] Anggoro, Dimas. (2016). Pengembangan modul bahan ajar sejarah berbasis perjuangan masyarakat tengaran kabupaten Semarang selama revolusi fisik untuk meningkatkan nasionalisme siswa SMA Negeri I Tengaran. Diambil pada tanggal 20 Juli 2019. https://eprints.uns.ac.id/26732/1/S861408017_pendahuluan.pdf 